\title{
LEGAL PROTECTION FOR BITCOIN INVESTORS IN INDONESIA: TO MOVE BEYOND THE CURRENT EXCHANGE SYSTEM
}

\author{
Mariske Myeke Tampi \\ * Dosen Fakultas Hukum Universitas Tarumanagara, Jakarta \\ Korespondensi: marisket@fh.untar.ac.id \\ Naskah dikirim: 22 Nopember 2016 \\ Naskah diterima untuk diterbitkan: 7 Maret 2017
}

\begin{abstract}
Bitcoin has attracted investors all over the world as it presents an appealing option to the current monetary system. It is a virtual currency that can potentially replace existing monetary currencies as it offers a new concept of payment known as mutual assent without relying on trust to any bank or decentralisation. Bitcoin as currency has been enacted in several countries, although responses had been wariness and cautions.

This paper will examine bitcoin related issues using a normative-juridical and critical approach in the context of the prevailing law in Indonesia, Law Number 11 of 2008 concerning Electronic Information and Transaction. So far, a similar law has been enacted by California, European Union and Singapore to deal with virtual currency matters. The aim of this paper is to describe bitcoin, why it currencies and how is the framework of legal protection to bitcoin investors in Indonesia.

Based on widely-spread adoption of bitcoin and the dark side of bitcoin cases shaping the government's stance on bitcoin in United States, this paper explores how to provide proper regulations to protect bitcoin investors in Indonesia.
\end{abstract}

Keywords: Bitcoin, virtual currency, legal protection

\begin{abstract}
Abstrak
Bitcoin telah menarik investor di seluruh dunia karena menyajikan pilihan yang menarik untuk sistem moneter saat ini. Ini adalah mata uang virtual yang dapat berpotensi menggantikan mata uang moneter yang ada karena menawarkan konsep baru pembayaran dikenal sebagai reksa persetujuan tanpa bergantung pada kepercayaan untuk setiap bank atau desentralisasi. Bitcoin sebagai mata uang telah diberlakukan di beberapa negara, meskipun tanggapan telah kecurigaan dan memperingatkan.

Makalah ini akan memeriksa bitcoin isu-isu terkait menggunakan pendekatan normatif-yuridis dan kritis dalam konteks hukum yang berlaku di Indonesia, Undang-Undang Nomor 11 Tahun 2008 tentang Informasi dan Transaksi
\end{abstract}


Elektronik. Sejauh ini, undang-undang serupa telah diberlakukan oleh California, Uni Eropa dan Singapura untuk menangani masalah-masalah mata uang virtual. Tujuan dari makalah ini adalah untuk menggambarkan bitcoin, mengapa mata uang dan bagaimana kerangka perlindungan hukum untuk Bitcoin investor di Indonesia.

Berdasarkan luas-tersebar adopsi bitcoin dan sisi gelap dari kasus bitcoin membentuk sikap pemerintah tentang bitcoin di Amerika Serikat, makalah ini mengeksplorasi bagaimana memberikan peraturan yang tepat untuk melindungi bitcoin investor di Indonesia.

Kata kunci: Bitcoin, mata uang virtual, perlindungan hukum

\section{A. Introduction}

Bitcoin is well known to many and has an increasing influence on the payment system as the number of people who are using it as a form of payment grows. In fact, bitcoin is becoming a phenomenon in the worldwide payment system as virtual currency offers a new concept of payment. The attraction of bitcoin can be seen in the figure ${ }^{1}$ depicting the number of bitcoin transaction for the last seven years.

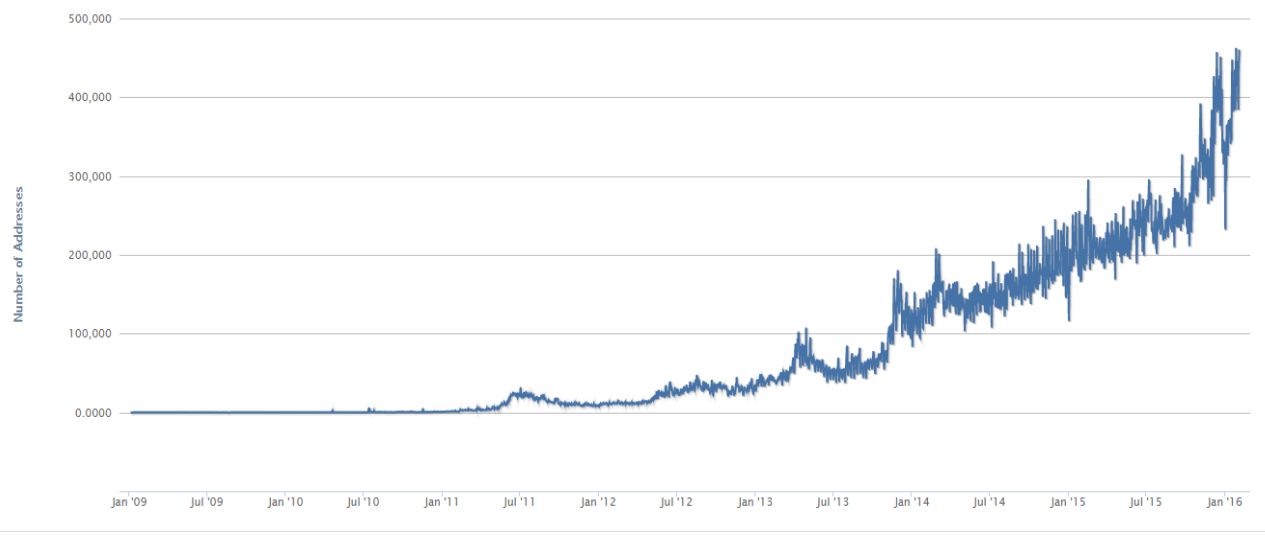

Figure 1.

Number of Bitcoin Transaction from January 2009 to January 2016

Bitcoin transactions from January 2009 to July 2011 were almost stagnant with less than 30.000 transactions. However from July 2009, the transactions grew rapidly and reached a peak of about 450.000 addresses. If bitcoin usage continues according to the above trend, it has the potential to become more wide-spreading.

The aim of this paper is to describe bitcoin, its role as a currency and the framework of the legal protection for bitcoin investors in Indonesia. In regards to the legal enactment of bitcoin in Indonesia, the framework of legal 
protection originates from other countries such as United States of America and European Union which have enacted vitual currency matters.

\section{B. What is Bitcoin?}

Bitcoin, also known as BTC, is a decentralized, peer-to peer network that allows the proof and transfer of ownership without the need for a trusted third party. ${ }^{2}$ The bitcoin payment system, first described by the pseudonymous Nakamoto $^{3}$ in 2008, is commonly referred to as a "cryptocurrency" 4 . A Bitcoin is basically a combination of a digital address and a number that is known as a private key. This key is a cryptographic tool that unlocks the bitcoins belonging to that address. The private key can be stored in any storage media, including a piece of physical paper, although many keep it in a software application known as a bitwallet. Despite many media images of coins, there is no official physical bitcoin. Bitcoins are not issued or backed by any government or central bank ${ }^{5}$, but are instead issued to the miners as rewards for being the first to solve the mathematical challenges needed to add a new block of transactions to the blockchain. ${ }^{6}$

As virtual currency ${ }^{7}$, bitcoins are computer files, like mp3s and gifs and stored in a program called a "wallet" or on an online service such as Coinbase. Bitcoin wallets can be on the hard drive of a user's personal computer or an

2 Goldman Sachs, “All About Bitcoin”, Global Macro Research, Issue 21, March 2014, Goldman Sachs Global Investment Research

${ }^{3}$ The name Satoshi Nakomoto appears to be a pseudonym and the identity of the real author or authors is unknown as of this writing.

${ }^{4}$ Bitcoin discussions also largely focus on the technology's well-publicized growing pains: wild price volatility, fraudulent investment schemes, multimillion dollar hacks. See Trevor Kiviat, "Beyond Bitcoin: Issue In Regulating Blockchain Transaction", Duke Law Journal, December 2015, Vol. 65 Issue 3, p569-608., 40p., p. 571

${ }^{5}$ Bitcoin is based on a decentralized protocol: There is no organization or government in control of its operation. As a consequence, there is no central entity able to apply monetary policy, and its supply has been set in advance. See Aviv Zohar, "Bitcoin: Under The Hood", Communications of the ACM, September 2015, Vol. 58 Issue 9, p104-113. 10p. DOI: 10.1145/2701411., p. 2

${ }^{6}$ James J. Angels and Douglas McCabe, "The Ethics of Payments: Paper, Plastic, or Bitcoin?”, January 14, 2014, http://dx.doi.org/10.2139/ssrn.2379233, p.4

${ }^{7}$ More about virtual currency, it has a slightly similar semantic meaning with virtual payment. The popular romantic comedy You've Got Mail (Nora Ephron, 1998) saw the owner of a small local bookstore match with the heir of a megabookstore chain likely to put her out of business. Barnes \& Noble had sued Amazon in 1997 for claiming to be "the world's largest bookstore," and yet few questioned the plot. Looking back, it seems obvious that Amazon would push out not only the small local bookstore but also the megabookstore chains and many other brick-and-mortar shops that sell a wide range of products. But it was not so obvious at the time. The Internet was neat. It made it easier to chat with loved ones and find new friends. However, it was difficult to imagine in the late 1990s all the ways in which it would touch our day to- day lives in the future-let alone which companies would come to dominate the landscape. Much the same might be said about the future of virtual payments with virtual currency today. See William J. Luther, "Bitcoin and The Future of Digital Payment", Independent Review, Winter 2016, Vol. 20 Issue 3, p397-404. 8p., p.4 
external hard drive. Like cash, bitcoins can be destroyed, lost or stolen. For instance, if a user stored their bitcoins on a computer that became inoperable after being dropped, or an external hard drive storing bitcoin was lost, those bitcoins would be irretrievable. Bitcoins can only be sent or received by logging the transaction on the public ledger, as in the aforementioned blockchain. ${ }^{8}$ Bitcoin can be digitally traded between users and can be purchased or exchanged over the internet for U.S. dollars, euros and other real or vitual currencies. ${ }^{9}$

\section{How Bitcoin Works?}

Nakamoto referred to it as "a system for electronic transactions without relying on trust" unlike traditional payments systems ${ }^{10}$. For example, users of paper checks trust that their banks will honor their checks, while users of debit cards maintain similar trust in their banks. Nakamoto's invention arose with this concern of a trusted intermediary, such as a bank to verify a transaction ${ }^{11}$. Instead of relying on a single trusted intermediary, such as a bank or credit card network to transmit and verify a transaction, the bitcoin system relies on a large number of competing "miners" to verify transaction.

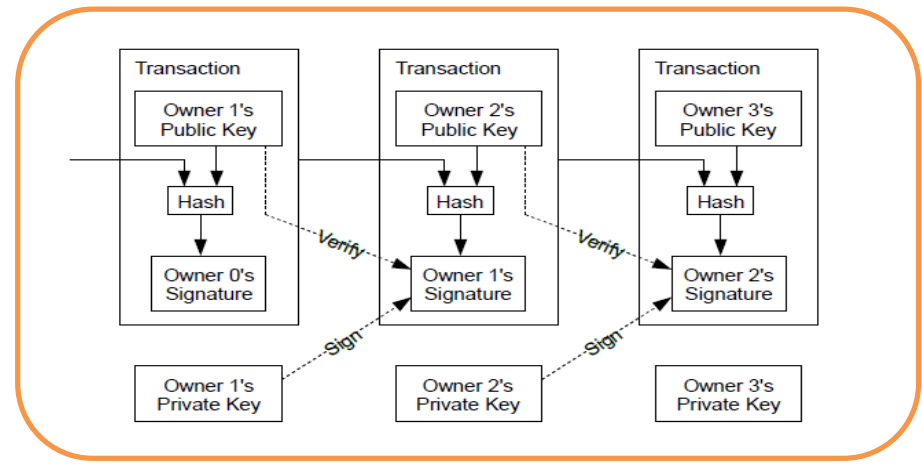

Figure 2.

Address owner uses key to authorize transfer

${ }^{8}$ Misha Tsukerman, "The Block Is Hot - A Survey of The State of Bitcoin Regulation and Suggestion for The Future", Berkeley Technology Law Journal, 2015, Vol. 30, p. 11271169, p.6

${ }^{9}$ Mark R. Parthemer and Sasha A. Klein, "Bitcoin: Change for a Dollar?", Journal of Financial Service Professionals, November 2014, Vol. 4, p. 16-18, p.17

${ }^{10}$ Invented as 'a peer-to-peer version of electronic cash [that] allows online payments to be sent directly from one party to another without going through a financial institution'. See Wim Raymaekers, Cryptocurrency Bitcoin: Disruption, Challenges and Opportunities, Journal of Payments Strategy \& Systems. Spring 2015, Vol. 9 Issue 1, p30-40. 11p., p.2. See also bitcoin could revolutionise our payment system and replace our cash-based society. Jarunee Wonglimpiyarat. Bitcoin: The revolution of the Payment System? Journal of Payments Strategy \& Systems. Winter2015/2016, Vol. 9 Issue 4, p230-240, p.1.

${ }^{11}$ Bitcoin is well suited for online transactions. It has no transaction fees and works well for international customers. Providing this convenience for the cult-following Bitcoin customer is the smart thing to do. See Michal Polasik, et. al., "Price Fluctuation and The Use of Bitcoin: An Empirical Inquiry", International Journal of Electronic Commerce. 2016, Vol. 20 Issue 1, p9-49. 41p. DOI: 10.1080/10864415.2016.1061413 
Nakamoto defined an electronic coin as a chain of digital signature. Each owner transfers the coin to the next by digitally signing a hash of the previous transaction and the public key to the next owner and adding these to the end of the coin. A miner as the receiver (payee) can verify the signatures to verify the chain of ownership. A public key assigns the ownership rights while a private key certifies the transaction. ${ }^{12}$

Anyone can become a miner of both sender or receiver by connecting a computer to the internet and running some mining software. In the bitcoin system, a transaction is publicly announced to the network. The miners effectively vote on legitimacy of each transaction as part of the mining process by time stamping each transaction and verifying that no one has double spent that money before. ${ }^{13}$

When purchasing or transacting with a bitcoin, an address is obtained. The address identifies to whom the bitcoin should be transferred, similar to a bank routing number on a check. Each address also has a corresponding private key known only to the owner, who can use it to authorize a future transfer. There are two addresses per transaction: one from the sender and one from the recipient. Addresses are made public through the public ledger known as "blockchain," which is a public registry that (1) records all bitcoin transactions and currency ownership interests, and (2) verifies that the sender sent his public key to the recipient and certified the transaction by signing with his private key. ${ }^{14}$

Miners verify the transaction on the block-chain, but anyone on the network can also use the public key to verify the transaction. Such public transparency supports the integrity of the bitcoin system and serves as a safety measure, since bitcoin transactions are irreversible. All transactions are recorded in the blockchain.

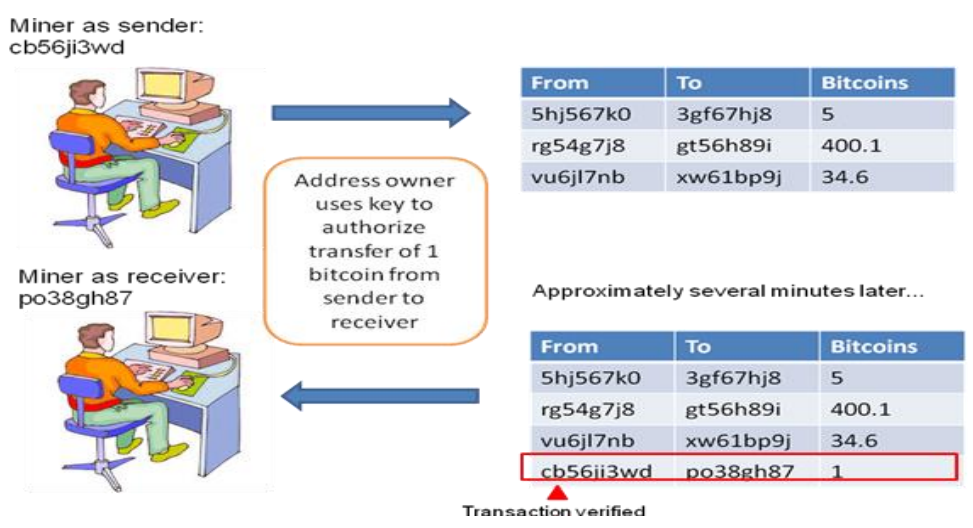

Figure 3.

Bitcoin transactions which are recorded in a public ledger known as the "blockchain"

12 Satoshi Nakamoto, "Bitcoin: A Peer-to-Peer Electronic Cash System", www.bitcoin.org, p. 2, accessed February 15, 2016

${ }^{13}$ Mark R. Parthemer and Sasha A. Klein, Op. Cit., p.16

${ }^{14}$ Ibid. 
Bitcoin transaction works using wallet. ${ }^{15}$ A wallet is a software of hardware through which we can conduct bitcoin transaction. Without a bitcoin wallet, we will not able to send or receive bitcoin payments. The wallet saves the bitcoin address and private key, i.e., the information needed to access and transfer a bitcoin. Bitcoin wallets like Airbitz, Breadwallet and CoPay can be downloaded.

\section{Legal Relationship of Bitcoin Transaction in Indonesia}

As a currency, bitcoin has a transaction unlike other currencies and hence a different legal relationship. Most currencies have a "triangle" type of transaction termed centralization where banks play a financial intermediary role between parties. The transfer of payment must be carried out through banks. On the other hand, a bitcoin transaction only needs two parties who mutually assent ${ }^{16}$ to exchange certain goods or currencies with a certain amount of bitcoins. This transaction is termed decentralization, not unlike the time when barter trading was done to gain their needs.

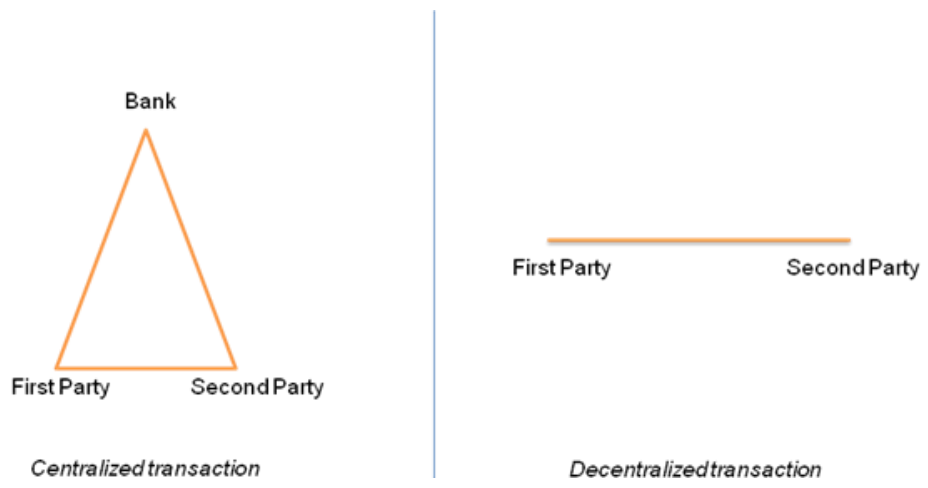

Figure 3.

The difference between centralized transaction and decentralized transaction

${ }^{15}$ https://www.weusecoins.com/en/getting-started/, accessed February 14, 2016

16 Parties to a contract must give some outward indication of their intention to be bound. Ordinarily, the parties show their mutual assent through an offer and an acceptance. One party proposes (offers) by words or conduct and the other agrees (accepts) by words or conduct. A contract expressed by words (whether oral or written) is an express contract. A contract formed by conduct is known as an implied contract. In determining whether or not both parties have actually agreed to the contract, the law applies an objective standard. That is, it looks to see if the intent of each of the parties can be ascertained from that party's words or actions. See Gerald R. Ferrera, Cyberlaw: Text and Cases, (Ohio: Thomson South Western, 2004), p. 156. Compare it with subtantive aspect of legal relationship that is agreed by both sender and receiver in bitcoin transaction. See Article 1338 juncto 1320 Indonesia Civil Code. 
The legal relationship is closely associated with basic values of communication such as confidentially, integrity, authenticity, non-repudiation ${ }^{17}$ and availability. Based on Figure 3, the key aspects of bitcoin transactions are:

\section{Confidentiality}

The system must have a privacy or ability to control access to bitcoin transactions, so that only authorized individuals can view sensitive information. Confidentiality is provided by having a public key to assign ownership rights and a private key to certify the transaction. Miners verify the transaction on the block-chain, but anyone on the network can also use the public key to verify the transaction.

\section{Integrity}

It is important that the information of each bitcoin transaction is accurate and reliable, and has not been subtly changed or tampered with by an unauthorized party. Blockchain records are kept of all of transactions.

\section{Authenticity}

This is correlated to the ability to verify the content of the bitcoin transaction cannot be changed in an unauthorized manner. All the transaction in blockchain are authentic.

\section{Non-repudiation}

Non-repudiation means that the origin of any action on the bitcoin system can be verified and associated with a user, with no possible denial. Every miner has their own key and certain record of transaction which comprises a combination of number and letter.

\section{Availability}

The information and other critical assets of bitcoin transaction must be accessible to miners and the business when needed.

As bitcoin transaction is similar to electronic transaction, all Indonesian bitcoin investors must bear in mind that the transaction is conducted through the World Wide $\mathrm{Web}^{18}$. Transactions can be conducted well if the computer ${ }^{19}$ and web are in good conditions. Input and output will be transferred if the system is running well.

${ }^{17}$ Edmon Makarim, Kompilasi Hukum Telematika, (Jakarta: RajaGrafindo Persada, 2003) p. 223

${ }^{18}$ The web is an application, that is, one of the services that uses internet platform. In its essence it is a global collection of interconnected and accesible resource. See Gerald R. Ferrera, et al., Cyber Law: Tax and Cases, (USA: South Western, 2012) p.10

${ }^{19}$ Computer system consists of hardware, software, brainware, procedures and data or information itself. See Edmon Makarim, Op. Cit, p. 223 


\section{E. Bitcoin as A Currency}

As transactions with bitcoins become developed in OECD countries, it is inevitable that it will come to Asia-Pasific, including Indonesia. A report by Goldman Sachs described bitcoin as an innovative payment technology but doubt it will evolve into a true alternative currency. ${ }^{20}$ In some places such as California, the European Union and Singapore, the bitcoin as a virtual currency has been regulated.

\section{California Code of Virtual Currency}

In the California Code of Virtual Currency, bitcoin is seen as a virtual currency. This is any type of digital unit that can be used as a medium of exchange or a form of digitally stored value - Chapter 1 of the California Code of Virtual currency, Assembly Bill No. 1326. "A person shall not engage in any virtual currency business in this state unless the person is licensed or exempt from licensure under this division." ${ }^{21}$ California officials had decided against further regulation of bitcoin under existing rules but instead requested legislature to address the issue. ${ }^{22}$

\section{European Union Law}

In European Union Law, bitcoin is regulated in Article 135 of the Value Added Tax (VAT) Directive where member states shall exempt the bitcoin transactions ${ }^{23}$. Transactions cited in this regulation included negotiation involving currency, bank notes and coins used as legal tender, with the exception of collectors' items, that is, gold, silver or other metal coins or bank notes which are not normally used as legal tender or coins of numismatic interest. The implication is that any person or organization using bitcoin is free from any obligation or liability.

\section{Monetary Authority of Singapore}

The Monetary Authority of Singapore became the first Asian regulator to bring bitcoin dealers under its regulation. The authority require dealers that buy, sell or facilitate the exchange of virtual currencies for real currencies "to verify the identities of their customers and report suspicious transactions" -- much as it requires of money changers -- the regulator said. The purpose, the statement said, is to prevent bitcoin from being used

\footnotetext{
${ }^{20}$ Carter Dougherty, "Goldman Sachs Sees Bitcoin Future in Payments Over Money”, http://www.bloomberg.com/news/articles/2014-03-12/goldman-sachs-sees-bitcoin-s-promisein-payments-over-currency, accessed February 14, 2016

${ }^{21}$ Chapter 2 California Code of Virtual currency, Assembly Bill No. 1326.

22 http://www.bloomberg.com/news/articles/2015-05-22/californiaagency-abandons-plans-to-regulate-digital-currency, James Nash, accessed January 22,2016

${ }^{23}$ http://curia.europa.eu/juris/document/document.jsf, accessed February 12, 2016
} 
in money laundering or terrorist financing. The regulator's responsibility "does not extend to the safety and soundness of virtual-currency intermediaries nor the proper functioning of virtual-currency transactions," the authority said. It added that bitcoin investors wouldn't be covered by the Securities and Futures Act and the Financial Advisers Act, which protect investors. The authority said its move will make Singapore "one of the first countries in the world to regulate virtual currency intermediaries" and that it will continue to monitor how the currency develops. ${ }^{24}$

\section{F. Applicable Law in Indonesia Concerning Bitcoin}

In regards to bitcoin regulation in Indonesia, Law Number 11 of 2008 Concerning Electronic Information and Transaction has enacted "electronic information" and "electronic transaction". According to definition of electronic information in Article 1 paragraph 1 of this Law:

"Electronic information means one cluster or clusters of electronic data, including but not limited to writings, sounds, images, maps, drafts, photographs, electronic data interchange (EDI), electronic mails, telegrams, telex, telecopy or the like, letters, signs, figures, access codes, symbols or perforations that have been processed for meaning or understandable to persons qualified to understand them.'

Therefore, bitcoin belongs to electronic data which is not limited by the definition of electronic information. Parts of bitcoin transaction such as blockchain, hash, public key and private key can be listed as sign and access code that have been processed for meaning or understandable to persons qualified to understand them. Article 5 paragraph 1 of this Law states that electronic information and/or electronic document and/or the print out is a valid proof.

Besides, according to the definition of electronic transaction that has been enacted in Article 1 paragraph 2 of this Law:

"Electronic transaction means a legal act that is committed by the use of computers, computer networks, and/or other electronic media."

Bitcoin transaction is done by the use of computer, but it has not been legally stipulated. It however does not imply that bitcoin is illegal. Similarly, in other laws regarding Futures Trading ${ }^{25}$ and Capital Market ${ }^{26}$ in Indonesia, there is no

${ }^{24}$ Ibid. Japan announced that it doesn't recognize bitcoin as a currency and won't regulate it as a financial product. In January, Taiwan barred physical bitcoin teller machines, and Hong Kong's regulator cautioned against the use of "virtual commodities such as bitcoin." In December, China's central bank banned financial institutions from offering bitcoin-related services.

${ }^{25}$ Law Number 10 of 2011 Concerning Amendments of Law Number 32 of 1997 Concerning Futures Trading

${ }^{26}$ Law Number 8 of 1995 Concerning Capital Markets 
regulation concerning bitcoin ${ }^{27}$. There is certainly much work for the Indonesia's regulator to respond these increasingly widespread bitcoin transactions.

\section{G. Consideration to Bitcoin Enactment in Indonesia}

Bitcoin Enactment in Indonesia should be derived from critical consideration of important aspects of bitcoin itself. Widely-spread of bitcoin, dark side of bitcoin, even cases shaping government's stance on bitcoin in another country should provide reliable inputs on how to enact the proper regulation of bitcoin in Indonesia.

\section{Widespread usage of Bitcoin}

Bitcoin with an exchange rate of about $646.60 \mathrm{US}^{28}$ has an increasing influence in the payment system as more and more people are willing to use it as a form of payment. It is timely for Indonesian regulator to enact a progressive legal approach towards business development involving bitcoin transaction. With more people putting their trust in bitcoin transaction, bitcoin will become more stable and the number of bitcoin investors in Indonesia can grow rapidly.

With regards to bitcoin regulation in Indonesia, the Indonesia Central Bank has conducted press-conference on February 6, 2014 ${ }^{29}$. Peter Jacobs, Director of Indonesia Central Bank issued a statement No : 16/6/DKom which contains restriction of bitcoin transaction ${ }^{30}$. He said that bitcoin has not constituted as a currency in Indonesia. Hence, all the risks associated with ownership and transaction of bitcoin should be borne by the owner of bitcoin.

\section{Dark Side of Bitcoin}

Besides it being widespread, there is a dark side of bitcoin which must be considered before its regulation. There are evidences that bitcoin has been

\footnotetext{
${ }^{27}$ Compare with the following opinion: It is a peculiar feature of our legal system that judges are often asked to rule on subjects they have little or no direct knowledge of - that a judge who balances his checkbook by hand will be asked to rule on bitcoin. Yet these may be the judges best positioned to apply enduring legal principles to cases that are "new in the instance," like jurisdictional disputes involving bitcoin. It is a judicial virtue to be able to rule correctly on a complex phenomenon without having to learn its detailed workings. Although some basic understanding is necessary, a judge does not need to know the intricacies of bitcoin to understand how to apply the rules of civil procedure to this new innovation. See Max Raskin, "Realm of The Coin - Bitcoin and Civil Procedure", Journal of Corporate \& Financial Law. 2015, Vol. 20 Issue 4, p969-1011. 43p., p. 2

${ }^{28} \mathrm{http}: / / \mathrm{wwW} . c o i n d e s k . c o m / p r i c e$, accessed July 26, 2016.

${ }^{29} \mathrm{http} / / /$ www.bi.go.id/id/ruang-media/siaran-pers/Pages/SP_160614.aspx

${ }^{30}$ The legal basis of his statement were Law Number 7 of 2011 Concerning Currency and Law Number 23 of 1999, as amended several times, most recently by Law Number 6 of 2009. Public urged to be wary of virtual currency known as bitcoin.
} 
utilized in supporting black markets, theft, and tax evasion, although cash remains the ultimate anonymous currency. The U.S. $\$ 100$ note is particularly popular for laundering the profits of illicit activities. Professor Edgar Feige estimates that U.S. currency is the preferred medium for "facilitating clandestine transactions, and for storing illicit and untaxed wealth." It is estimated that over 50 percent of all hard currency in most countries is used to hide transactions. These illicit transactions include illegal trade in drugs as well as unreported income to skirt the tax code. In many ways, bitcoin and cash share a key property that makes them both suitable for unlawful activity: neither requires an institutional (and subpoenable) intermediary. ${ }^{31}$

\section{Volatility of bitcoin}

According to the Efficient-Markets Hypothesis (EMH) ${ }^{32}$, which is still the dominant hypothesis in the analysis of financial markets, it is impossible for bitcoins to sustain their value. The EMH states that the market value of an asset is equal to the best available estimate of the value of the income flows it will generate. As bitcoins do not generate any earnings and have no intrinsic value, they must appreciate in value to ensure that people are willing to hold them.

However, the bitcoin is a self-described digital currency. However, most bitcoin users are acquiring it as a speculative investment, rather than with the intent to purchase goods. This conclusion is evidenced by the fact that demand for bitcoins is growing with increased public attention, while the actual usage of bitcoins remains constant.67 Some exchanges show 80\% of bitcoin users purchase it as a speculative tool. ${ }^{33}$ There are many risks to investing in bitcoins. The SEC, Financial Industry Regulatory Industry (FINRA), and the North American Securities Administrators Association (NASAA) all issued warnings to investors about the dangers of digital currencies. The SEC warns that investments involving bitcoins may have a heightened risk of fraudulent or high-risk investment schemes. FINRA warns that bitcoin prices have fluctuated considerably and investors may be subject to large losses. The NASAA included digital currencies on their list of top investor threats. Bitcoin investors face several other risks. As

${ }^{31}$ Misha Tsukerman, Op. Cit, p. 1147

${ }^{32}$ Nicole D. Swartz, "Bursting the Bitcoin Bubble: The Case To Regulate Digital Currency as a Security or Commodity", Tulane Journal of Technology \& Intellectual Property, Fall 2014, Vol. 17, p319-335, p.9

${ }^{33}$ See Campbell R. Harvey, "Do Cryptocurrencies Such as Bitcoin Have a Future? Yes: Don't Judge Bitcoin by Its Early, Inevitable Problems", Wall Street Journal - Eastern Edition. 3/2/2015, Vol. 265 Issue 49, p.1. The article advocates for the viability of electronic currencies such as bitcoins. The author says the block chain bitcoins use to record transactions could also provide a way to verify ownership of property and establish contracts. He maintains the volatility of bitcoin prices are due to the currency's illiquidity, which will subside over time. 
with any investment, there is also the possibility that insider information can affect the investment's value. ${ }^{34}$

\section{Cases Shaping Government's Stance on Bitcoin in United States}

As federal and state agencies continue to tackle the regulation of bitcoin, courts have been forced to define bitcoin in the course of recent litigation. In a series of recent developments, U.S. state banking regulators also have indicated that financial regulatory requirements should extend to activity involving bitcoin and other virtual currencies ${ }^{35}$. Below are four key cases shaping government's stance on bitcoins. ${ }^{36}$ All the judges defined bitcoin as money so as to subject it to the Securities Act, act and federal money laundering statutes. ${ }^{37}$

\section{a. SEC v. Shavers}

Defendant Trendon T. Shavers founded and operated Bitcoin Savings and Trust (BTCST), which was subsequently declared a Ponzi scheme used to defraud investors by Magistrate Judge Amos Mazzant of the Eastern District of Texas. ${ }^{38}$ BTCST was an unincorporated online investment scheme in which Shavers solicited and accepted all investments and paid all purpoted returns, in the virtual currency known as bitcoin. ${ }^{39}$ Judge Mazzant found that Shavers met the definition of investment contract and were thus securities, giving the court jurisdiction over the case through the Securities Act. ${ }^{40}$

In an earlier memorandum to establish the court's subject matter jurisdiction, Judge Mazzant declared the bitcoin to be a form of currency. ${ }^{41}$ The Securities Act defines a "security" as "any ...

${ }^{34}$ A statistical research has been conduct to analyze the exchange rate of Bitcoin versus USD using fifteen of the most popular parametric distributions in finance, the most comprehensive collection of distributions ever fitted

to any exchange rate data. They have found that the generalized hyperbolic distribution gives the best fit. Chu Jeffrey, Nadarajah Saralees, et.al., "Statistical Analysis of the Exchange Rate of Bitcoin", PLoS One Journal,Vol. 10 Issue 7, p1-27. DOI: 10.1371/journal.pone.0133678, p.24

${ }^{35}$ Conrad Bahlke, Ghebrekristos Adam, et.al., "Recent Development in the Regulatory Treatment of Bitcoin”, Intellectual Property \& Technology Law Journal, Jan2016, Vol. 28 Issue 1, p6-8. p.8

${ }^{36}$ Michael B. Marois \& Carter Dougherty, "California Says State Law Grants Right to Oversee Bitcoin”, Bloomberg.com http://www.bloomberg.com/news/2014-1204/california-says-state-law-grants-right-to-oversee-bitcoin.html, accesed February 14, 2016

${ }^{37}$ Misha Tsukerman, Op. Cit., p. 1164

${ }^{38}$ Secs.\& Exch. Comm'n v. Shavers, No. 4:13-CV-416, 2014 WL 4652121 (E.D. Tex. Sept. 18, 2014), http://www.law.du.edu/documents/corporate-governance/securitiesmatters/shavers/SEC-v-Shavers-No-4-13-CV-416-E-D-Tex-Sept-18-2014.pdf

${ }^{39}$ Ibid., p. 1

${ }^{40}$ Ibid.

${ }^{41}$ Ibid., p. 25 
investment contract." 42 An investment contract is defined as "any contract, transaction, or scheme involving: (1) an investment of money; (2) in a common enterprise; (3) with the expectation that profits will be derived from the efforts of the promoter or a third party. ${ }^{43}$ Thus, the treshold question for the court was whether the bitcoins invested into Shaver's Ponzi scheme qualified as an investment of money. Judge Mazzant reasoned that because bitcoins can be used to purchase goods or services, pay for individual living expenses and be exchanged for fiat currencies, bitcoins constituted an investment of money or "reserve fund". ${ }^{4}$

\section{b. United States v. Faiella}

In the Southern District of New York and elsewhere, Robert M. Faiella, a.k.a "BTCKing", the defendant, knowingly did conduct, control, manage, supervise, direct and own all and part of a money transmitting business affecting interstate and foreign commerce, to wit, a bitcoin exchange service FAIELLA operated on the "Silk Road" website under the username "BTCKing" which: (1) failed to comply with the money transmitting business registration requirements set forth in Title 31, United States Code, Section 5330 and the regulations prescribed thereunder and (2) otherwise involved the transportation and transmission of funds to Faillla to have been intended to be used to promote and support unlawful activity, to wit, narcotics trafficking on the "Silk Road" website, in violation of Title 21, United States Code, Sections 812,841 and $846 .{ }^{45}$

Defendants Robert Faiella and Charlie Shrem were accused of operating an unlicensed money transmitting business and conspiring to commit money laundering in connection with Silk Road. ${ }^{46}$ The defendants moved to dismiss the indictment by arguing that bitcoin did not qualify as "money" under racketeeting laws, and that operating a bitcoin exchange does not constitute "transmitting money" under 18 . U.S.C. $\S 1960 .{ }^{47}$

Judge Rakoff rejected the defendants' arguments, reasoning that bitcoin clearly qualifies as "money" or "funds" using plain meaning definitions found in the dictionary as it "can be easily purchased in exchange for ordinary currency, act as a denominator of value and is used to conduct financial transactions. ${ }^{48}$ The court found this definition consistent with the legislative history of $\S 1960$, which was passed to prevent money

${ }^{42}$ Ibid., p. 12

${ }^{43}$ Ibid.

${ }^{44}$ Ibid., p. 16

45 United States v. Faiella, 39 F. Supp. 3d 544, 545-47 (S.D.N.Y. 2014), www.assetsearchblog.com/files/2014/03/Shrem-Docket-Report.pdf

${ }^{46} \mathrm{Ibid}$.

${ }^{47}$ Ibid.

${ }^{48}$ Ibid.,p.4 
laundering in connection with drug dealing. The court also found that Congress chose to use the term "funds" to keep up with the evolving methods of money launderers. Judge Rakoff went to further define the defendant's activities as "transmitting money" and thus qualifying the as "money transmitters" and subject to FinCEN's virtual currency guidance. ${ }^{49}$

\section{c. United States v. Ulbricht}

Around January 2011, Ross William Ulbricht, a.k.a "Dread Pirate Roberts" (DPR) crated an underground website known as "Silk Road" designed to enable users across the world to buy and sell illegal drugs and other illicit goods and services anonymously and ouside the reach of law enforcement. ${ }^{50}$ During that time, Silk Road emerged as the most sophisticated and extensive criminal marketplace on the internet. He was challenged the applicapility of money laundering laws to virtual currency. Judge Katherine Forrest ruled that as an initial matter the use of bitcoins for payment is insufficient in and of itself to state a claim for money laundering and that anonymous transactions are not crimes. Instead, the basis of the charge was the use of bitcoin to shield unlawful activities such as narcotics trafficking and, in Ulbricht's case, computer hacking from third party discovery. ${ }^{51}$

Ulbricht also brought a similar argument as the defendants in Faiella, arguing that bitcoins did not qualify as "funds" for the purposes of money laundering statutes. Judge Forrest found Ulbricht's argument unavailing and by using similar reasoning to Judge Rakoff, she held that "money" and funds" were simply methods to pay for things and thus the terms covered bitcoins. Judge Forrest noted that bitcoins' "sole raison d'etre" was to pay for things and any other reading would be "nonsensical". 52

\section{H. Conclusion}

There are two important conclusions based on the considerations above for the wider adoption of bitcoin regulation in Indonesia:

1. In response to the widespread bitcoin, the regulator should take a progressive policy to enacte bitcoin as a currency

\footnotetext{
${ }^{49}$ Ibid.

${ }^{50}$ United States v. Ulbricht, 31 F. Supp. 3d 540, 548 (S.D.N.Y. 2014), http://www.justice.gov/sites/default/files/usaosdny/legacy/2015/03/25/US\%20v.\%20Ross\%20Ulbricht\%20Indictment.pdf accessed February 12,2016

${ }^{51} \mathrm{Ibid}$.

${ }^{52}$ Ibid.
} 
2. With regards to the darkside of bitcoin, since the transactions recorded in blockchain are anonymous, there should be a license for those who are willing to transact bitcoins. The authority can then trace the bitcoin's account owner in Indonesia to minimize the misuse of bitcoin transactions.

Through the proper enactment of bitcoin, Indonesia can enable its citizens to move beyond the current exchange system to embrace a widespread bitcoin transaction model to conduct business.

\section{BIBLIOGRAPHY}

\section{Books}

Ferrera, Gerald R. Cyberlaw: Text and Cases. USA: South Western, 2004.

Ferrera, Gerald R., et al. Cyber Law: Tax and Cases. USA: South Western, 2012.

Gibney, Frank. Pacific Ties: The United States of America and An emerging 'Pacific community'? in Anthony McGrew and Christopher Brook, ed. The Open University: New York,1998.

Makarim, Edmon. Kompilasi Hukum Telematika. Jakarta: RajaGrafindo Persada, 2003.

\section{Regulations}

California Code of Virtual Currency, Assembly Bill No. 1326

Indonesia Civil Code

Law Number 10 of 2011 Concerning Amendments of Law Number 32 of 1997 Concerning Futures Trading

Law Number 8 of 1995 Concerning Capital Markets

Law Number 7 of 2011 Concerning Currency

Value Added Tax Directive

\section{Journals}

Angels, James J. and Douglas McCabe. "The Ethics of Payments: Paper, Plastic, or Bitcoin?". Business Ethics Journal. January 2014. http://dx.doi.org/10.2139/ssrn.2379233

Bahlke, Conrad, et.al. "Recent Development in the Regulatory Treatment of Bitcoin". Intellectual Property \& Technology Law Journal. Jan 2016. Vol. 28, Issue 1.

Goldman Sachs. “All About Bitcoin: Global Macro Research”. Issue 21. March 2014. Goldman Sachs Global Investment Research

Harvey, Campbell R. "Do Cryptocurrencies Such as Bitcoin Have a Future? Yes: Don't Judge Bitcoin by Its Early, Inevitable Problems". Wall Street Journal - Eastern Edition. Vol. 265, Issue 49.

Jeffrey, Chu, et.al. "Statistical Analysis of the Exchange Rate of Bitcoin". PLoS One Journal. Vol. 10, Issue 7. DOI: 10.1371/journal.pone.0133678 
Kiviat, Trevor. "Beyond Bitcoin: Issue In Regulating Blockchain Transaction".

Duke Law Journal. December 2015. Vol. 65 Issue 3. p569-608. 40p.

Luther, William J. "Bitcoin and The Future of Digital Payment". Independent Review. Winter 2016. Vol. 20 Issue 3. p397-404. 8p.

Parthemer, Mark R. and Sasha A. Klein. "Bitcoin: Change for a Dollar?". Journal of Financial Service Professionals. November 2014, Vol. 4, p. 16-18

Polasik, Michal, et. al. "Price Fluctuation and The Use of Bitcoin: An Empirical Inquiry". International Journal of Electronic Commerce. 2016. Vol. 20 Issue 1. p9-49. 41p. DOI: 10.1080/10864415.2016.1061413

Raskin, Max. "Realm of The Coin - Bitcoin and Civil Procedure". Journal of Corporate \& Financial Law. 2015. Vol. 20 Issue 4. p969-1011. 43p.

Raymaekers, Wim. "Cryptocurrency Bitcoin: Disruption, Challenges and Opportunities”. Journal of Payments Strategy \& Systems. Spring 2015. Vol. 9 Issue 1. p30-40. 11p.

Tsukerman, Misha. "The Block Is Hot - A Survey of The State of Bitcoin Regulation And Suggestion For The Future". Berkeley Technology Law Journal. 2015. Vol. 30. p.1127-1169

Tridevi, Anjani. "Closer Bitcoin Scrunity On Way". The Wall Street JournalEastern Edition,.Vol. 263: 60. March 2014. http://libproxy1.nus.edu.sg/login?url=http://search.proquest.com/docview /1507139629? accountid=13876

Swartz, Nicole D. "Bursting the Bitcoin Bubble: The Case To Regulate Digital Currency as a Security or Commodity". Tulane Journal of Technology \& Intellectual Property. Fall 2014. Vol. 17.

Wonglimpiyarat, Jarunee. "Bitcoin: The revolution of the Payment System?" Journal of Payments Strategy \& Systems. Winter 2015/2016. Vol. 9, Issue 4.

Zohar, Aviv. "Bitcoin: Under The Hood Communications of the ACM". September 2015. Vol. 58 Issue 9. p104-113. 10p. DOI: 10.1145/2701411.

\section{Cases}

United States v. Faiella, 39 F. Supp. 3d 544, 545-47 (S.D.N.Y. 2014), www.assetsearchblog.com/files/2014/03/Shrem-Docket-Report.pdf, accessed February 12, 2016

United States v. Ulbricht, 31 F. Supp. 3d 540, 548 (S.D.N.Y. 2014), http://www.justice.gov/sites/default/files/usaosdny/legacy/2015/03/25/US\%20v.\%20Ross\%20Ulbricht\%20Indictment. pdf, accessed February 12, 2016

Secs.\& Exch. Comm'n v. Shavers, No. 4:13-CV-416, 2014 WL 4652121 (E.D. Tex. Sept. 18, 2014), http://www.law.du.edu/documents/corporategovernance/securities-matters/shavers/SEC-v-Shavers-No-4-13-CV-416E-D-Tex-Sept-18-2014.pdf, accessed February 12, 2016 


\section{Websites}

Dougherty, Carter. "Goldman Sachs Sees Bitcoin Future in Payments Over Money". http://www.bloomberg.com/news/articles/2014-03-12/goldmansachs-sees-bitcoin-s-promise-in-payments-over-currency. Accessed February 14, 2016

Marois, Michael B. \& Carter Dougherty. "California Says State Law Grants Right to Oversee Bitcoin". Bloomberg.com http://www.bloomberg.com/news/2014-12-04/california-says-state-lawgrants-right-to-oversee-bitcoin.html. Accesed February 14, 2016

Nakamoto, Satoshi. "Bitcoin: A Peer-to-Peer Electronic Cash System". www.bitcoin.org. Accessed February 15, 2016

Nash, James. "California Agency Abandons Plans To Regulate Digital Currency". $\quad$ http://www.bloomberg.com/news/articles/2015-0522/california-agency-abandons-plans-to-regulate-digital-currency. Accessed January 22, 2016 https://blockchain.info/charts/n-unique. Accessed February 14, 2016 https://www.weusecoins.com/en/getting-started/. Accessed February 14, 2016 http://www.coindesk.com/price. Accessed July 26, 2016 http://www.bi.go.id/id/ruang-media/siaran-pers/Pages/SP_160614.aspx. Accesed February 14, 2016

http://curia.europa.eu/juris/document/document.jsf. Accessed February 12, 2016 